\title{
PROGRAM APLIKASI OPTIMALISASI PERENCANAAN PRODUKSI DENGAN METODE GOAL PROGRAMMING (KASUS CV. G)
}

\author{
Zahedi $^{1}$; I Wayan Aditya Eka Putera ${ }^{2}$ \\ ${ }^{1,2}$ Jurusan Matematika dan Statistik, Fakultas Sains dan Teknologi, \\ Universitas Bina Nusantara, Jln. K.H. Syahdan No. 9, Palmerah, Jakarta Barat 11480 \\ zahedizahedi@binus.ac.id; wayan_aditya@yahoo.co.id
}

\begin{abstract}
Indonesia today is still a State agrarian. Thus agriculture in Indonesia always get more attention by the government. Many government programs are rolled out to support the agricultural development of Indonesia, and one of them is the fertilizer subsidy to farmers Indonesia. Fertilizer itself is very useful to nourish the soil and provide vitamins to the plants, thus increasing the amount of production generated. Therefore it is necessary fertilizer for agriculture in Indonesia. CV. G company is one of the companies that produce fertilizer. Fertilizer produced by this company is an organic fertilizer and inorganic fertilizer. Problems faced by these companies are in planning the production of fertilizer produced. Companies want to optimize the amount of production of each fertilizer, maximize revenues, minimize production costs, and simultaneously optimize the working hours of employees. To meet these objectives, this research created program package using goal programming methods. Goal programming method can provide an effective solution / equilibrium toward the goals set, and the calculation will be assisted by using the Simplex method that has been modified. This method is an extension of linear programming, linear programming which can only solve problems with a single goal while the goal programming to solve problems with multiple objectives.
\end{abstract}

Keywords: goal programming, optimization, linear programming, production planning

\begin{abstract}
ABSTRAK
Indonesia sampai saat ini masih menjadi negara agraris. Maka dari itu pertanian di Indonesia selalu memperoleh perhatian lebih oleh pemerintah. Banyak program dari pemerintah yang digulirkan untuk mendukung kemajuan pertanian Indonesia, dan salah satunya adalah subsidi pupuk untuk petani-petani Indonesia. Pupuk sendiri sangatlah berguna untuk menyuburkan tanah serta memberikan vitamin kepada tanaman, sehingga dapat meningkatkan jumlah produksi yang dihasilkan. Maka dari itu pupuk sangatlah diperlukan bagi pertanian di Indonesia. CV. G merupakan salah satu perusahaan yang memproduksi pupuk. Pupuk yang diproduksi oleh perusahaan ini adalah pupuk organik dan pupuk anorganik. Permasalahan yang dihadapi oleh perusahaan ini adalah didalam perencanaan produksi pupuk yang dihasilkan. Perusahaan ingin mengoptimalkan jumlah produksi masing-masing pupuk, memaksimalkan pendapatan, meminimalkan biaya produksi, dan sekaligus mengoptimalkan jam kerja karyawan. Untuk dapat memenuhi tujuan-tujuan tersebut, dirancang suatu paket program dengan menggunakan metode goal programming. Metode goal programming mampu memberikan solusi yang efektif / setimbang terhadap tujuan-tujuan yang telah ditetapkan, dan dalam perhitungannya akan dibantu dengan menggunakan metode simpleks yang telah dimodifikasi. Metode ini merupakan perluasan dari linear programming, di mana linear programming hanya mampu memecahkan masalah dengan tujuan tunggal sedangkan goal programming mampu memecahkan masalah dengan tujuan berganda.
\end{abstract}

Kata kunci: goal programming, optimalisasi, linear programming, perencanaan produksi 


\section{PENDAHULUAN}

Indonesia sampai saat ini masihlah menjadi Negara agraris. Maka dari itu pertanian di Indonesia selalu memperoleh perhatian lebih oleh pemerintah. Banyak program dari pemerintah yang digulirkan untuk mendukung kemajuan pertanian Indonesia, dan salah satunya adalah subsidi pupuk untuk petani-petani Indonesia. Pupuk sendiri sangatlah berguna untuk menyuburkan tanah serta memberikan vitamin kepada tanaman, sehingga dapat meningkatkan jumlah produksi yang dihasilkan. Maka dari itu pupuk sangatlah diperlukan bagi pertanian di Indonesia.

Berdasarkan data dari Badan Pertanian luas perkebunan di Indonesia sekitar 15 juta hectare di tahun 2002. Oleh karena itu untuk dapat mengelola tanah perkebunan dengan baik serta agar dapat memperoleh hasil yang maksimal maka pupuk sangatlah diperlukan. Data proyeksi kebutuhan pupuk perkebunan di tahun 2010 menurut Direktorat Jenderal Perkebunan adalah pupuk urea sejumlah 2.560.214 ton, Superphos sejumlah 1.745.060 ton, ZA sejumlah 350.966, NPK sejumlah 5.809.476 ton, $\mathrm{KCl}$ sejumlah 2.060.791 ton dan Organik sejumlah 1.489.796 ton.

Melihat adanya peluang tersebut, maka banyak perusahaan yang bermunculan yang bergerak dibidang pembuatan pupuk. Oleh karena itu persaingan pun menjadi lebih ketat. Untuk dapat bertahan dari persaingan ini maka setiap keputusan yang diambil sangatlah berpengaruh besar didalam kehidupan suatu perusahaan. Maka dari itu didalam suatu perusahaan perencanaan produksi sangatlah berperan penting. Perencanaan produksi sendiri dapat dibagi menjadi 3 elemen, yaitu konsumen, produk, dan proses manufaktur/produksi. Elemen konsumen disini yaitu target pasar yang akan menjadi sasaran. Elemen produk adalah kualitas serta keunggulan dari produk yang dihasilkan. Elemen manufaktur/produksi adalah pembuatan suatu produk dengan jumlah yang tepat dan meminimalisasi biaya produksi yang ada.

CV. G merupakan perusahaan yang baru berdiri yang bergerak di bidang pembuatan pupuk. Perusahaan ini berdiri pada 2007 di atas lahan seluas lebih kurang dua hektare. Pupuk yang diproduksi oleh perusahaan ini ada dua macam yaitu pupuk organik dan pupuk anorganik. Pupuk ini dibuat melalui mesin- mesin yang memang khusus dirancang untuk pembuatan pupuk untuk dapat menghasilkan kualitas pupuk yang lebih homogen dan dapat memproduksi pupuk dalam jumlah besar. Perusahaan ini didalam perkembangannya memerlukan perencanaan produksi yang tepat agar perusahaan ini dapat memaksimalkan pendapatan penjualan, meminimalkan biaya produksi, dan memaksimalkan jumlah produksi. Untuk dapat menganalisa dan membuat solusi dari permasalahan tersebut maka dapat digunakan metode goal programming. Dengan metode goal programming, maka tujuan tersebut akan dapat dibuat formulasinya dan mampu memberikan hasil yang efisien.

\section{METODE PENELITIAN}

\section{Perencanaan Produksi}

Perencanaan produksi merupakan perencanaan tentang produk apa dan berapa yang akan diproduksi oleh perusahaan yang bersangkutan dalam satu periode yang akan datang. Perencanaan produksi merupakan bagian dari perencanaan operasional di dalam perusahaan. Dalam penyusunan perencanaan produksi, hal yang perlu dipertimbangkan adalah adanya optimasi produksi sehingga akan dapat dicapai tingkat biaya yang paling rendah untuk pelaksanaan proses produksi tersebut.

Perencanaan produksi juga dapat didefinisikan sebagai proses untuk memproduksi barangbarang pada suatu periode tertentu sesuai dengan yang diramalkan atau dijadwalkan melalui 
pengorganisasian sumber daya seperti tenaga kerja, bahan baku, mesin dan peralatan lainnya. Perencanaan produksi menuntut penaksir atas permintaan produk atau jasa yang diharapkan akan disediakan perusahaan di masa yang akan datang. Dengan demikian, peramalan merupakan bagian integral dari perencanaan produksi.

\section{Penelitian Terkait}

Dauzere-Peres, et al. (2000) menyelesaikan problem perencanaan produksi yang memperhatikan kedatangan bahan baku koninu. Penelitian ini menamakan problem ini sebagai problem perencanaan produksi kontinu. Problem diselesaikan dengan menemukan laju produksi optimal. Linear programming digunakan untuk menyelesaikan problem ini. Ching and Zhou (1996) membahas model produksi satu mesin dengan memperhatikan persediaan. Model yang dikembangkan menggunakan Goal Programming dengan tujuan menemukan optimal hedging point untuk mesin produksi. Huang et al. (1996) memperhatikan strategi persediaan dan peningkatan produksi, tujuan dari penelitian adalah keseimbangan persediaan, menaikkan produksi, dan mengurangi backlogged demand. Perkins dan Srikant (1996) mengembangkan model fluid-flow untuk system produksi untuk meminimasi persediaan dan memaksimalkan produksi dan meminimasi shortfall costs dengan goal programming.

Penelitian ini akan merancang model optimisasi produksi dengan menggunakan goal programming dengan tujuan memaksimalkan pendapatan penjualan, meminimalkan biaya produksi, dan memaksimalkan jumlah produksi.

\section{Goal Programming}

Goal programming adalah suatu metode yang dikembangkan dari Linear programming, di mana pada linear programming masalah yang dapat diselesaikan hanya memiliki satu tujuan /goal. Namun pada kenyataannya dikehidupan sehari-hari masalah yang dihadapi tidaklah hanya satu namun bisa lebih dari satu dan memiliki banyak goal. Oleh karena itu metode goal programming ini dapat digunakan untuk masalah-masalah yang memiliki banyak goal. Hasil dari metode ini adalah solusi yang efisien (efficient solution) karena hasil yang diperoleh bisa jadi tidak optimal terhadap semua masalah yang ada.

Metode goal programming sendiri dikembangkan oleh A. Charnes dan W.M. Cooper. Karena metode goal programming merupakan perluasan dari model pemrograman linear, maka seluruh asumsi, notasi, formulasi model matematis, prosedur perumusan model dan penyelesaiannya tidaklah jauh berbeda. Perbedaan hanya terletak pada kehadiran sepasang variabel deviasional yang akan muncul di fungsi tujuan dan di fungsi-fungsi kendala.

Variabel deviasional berfungsi untuk menampung penyimpangan atau deviasi yang akan terjadi pada nilai ruas kiri suatu persamaan kendala terhadap nilai ruas kanannya. Agar deviasi itu minimum, artinya nilai ruas kiri suatu persamaan kendala sebisa mungkin mendekati nilai ruas kanannya maka variabel deviasional itu harus diminimumkan di dalam fungsi tujuan.

Pada goal programming kendala-kendala merupakan sarana untuk mewujudkan sasaran yang hendak dicapai. Sasaran-sasaran, dalam hal ini, dinyatakan sebagai nilai konstan pada ruas kanan kendala. Sebagai contoh, sasaran laba, anggaran yang tersedia, resiko investasi, dan lain-lain. Mewujudkan suatu sasaran, dengan demikian, berarti mengusahakan agar nilai ruas kiri suatu persamaan kendala sama dengan nilai ruas kanannya. Itulah sebabnya kendala-kendala di dalam motode goal programming selalu berupa persamaan dan dinamakan kendala sasaran. Di samping itu, keberadaan sebuah kendala sasaran selalu ditandai oleh kehadiran variabel deviasional sehingga setap kendala sasaran pasti memiliki variabel deviasional. 


\section{Pemodelan Goal Programming}

Konsep dari goal programming adalah adanya variabel deviasional. Variabel deviasional sendiri dapat dibedakan menjadi dua yaitu sebagai berikut.

Pertama, variabel deviasional untuk menampung deviasi yang berada di bawah sasaran yang dikehendaki. Sasaran itu tercermin pada nilai ruas kanan suatu kendala sasaran. Dengan kata lain, variabel deviasional ini berfungsi untuk menampung deviasi negatif. Notasi $D B$ digunakan untuk menandai jenis variabel deviasional ini. Karena variabel deviasional DB berfungsi untuk menampung deviasi negatif, maka:

$$
\sum_{i=1}^{n} a_{i j} X_{i j i}=b_{i}-D B_{i}
$$

atau

$$
\sum_{i=1}^{n} a_{i j} X_{i j}+D B_{i}=b_{i}
$$

di mana,

$$
\begin{aligned}
& i=1,2, \ldots, \mathrm{m} \\
& j=1,2, \ldots, \mathrm{n}
\end{aligned}
$$

sehingga DB akan selalu mempunyai koefisien +1 pada seitap kendala sasaran.

Kedua, variabel deviasional untuk menampung deviasi yang berada di atas sasaran. Dengan kata lain, variabel deviasional ini berfungsi untuk menampung deviasi positif. Notasi DA digunakan untuk menandai jenis variabel deviasional ini. Karena variabel deviasional DA berfungsi untuk menampung deviasi positif, maka:

$$
\sum_{i=1}^{n} a_{i j} X_{i j}=b_{i}+D A_{i}
$$

atau

$$
\sum_{j=1}^{n} a_{i j} X_{i j}-D A_{i}=b_{i}
$$

di mana

$$
\begin{aligned}
& i=1,2, \ldots, \mathrm{m} \\
& j=1,2, \ldots, \mathrm{n}
\end{aligned}
$$

sehingga DA akan selalu mempunyai koefisien -1 pada setiap kendala sasaran.

Secara matematis, bentuk umum kendala sasaran itu adalah:

$$
\sum_{j=1}^{m} a_{i j} X_{i j}-D A_{i}+D B_{i}=b_{i}
$$

Dalam hal ini, ada tiga kemungkinan yang akan terjadi, yaitu:

Pertama, $\mathrm{DA}_{\mathrm{i}}=\mathrm{DB}_{\mathrm{i}}=0$, sehingga menjadi: 


$$
\sum_{j=1}^{\mathrm{n}} a_{i j}+X_{i j}=b_{i}
$$

atau dikatakan bahwa sasaran tercapai.

Kedua, $\mathrm{DB}_{\mathrm{i}}>0$ dan $\mathrm{DA}_{\mathrm{i}}=0$, sehingga menjadi:

$$
\sum_{j=1}^{n} a_{i j} X_{i j}=b_{i}-D B_{i}
$$

atau dikatakan bahwa hasil di bawah sasaran karena

$$
\sum_{j=1}^{n} a_{i j} X_{i j}<b_{i}
$$

Ketiga, $\mathrm{DB}_{\mathrm{i}}=0$ dan $\mathrm{DA}_{\mathrm{i}}>0$ sehingga menjadi:

$$
\sum_{j=1}^{n} a_{i j} X_{i j}=b_{i}+D A_{i}
$$

atau dikatakan bahwa hasil di atas sasaran karena

$$
\sum_{j=1}^{n} a_{i j} \cdot x_{i j}>b_{i}
$$

Sasaran yang telah ditetapkan $\left(b_{i}\right)$ akan tercapai bila variabel deviasional $\mathrm{DA}_{\mathrm{i}}$ dan $\mathrm{DB}_{\mathrm{i}}$ bernilai nol. Oleh karena itu, $\mathrm{DA}_{\mathrm{i}}$ dan $\mathrm{DB}_{\mathrm{i}}$ harus diminimumkan di dalam fungsi tujuan, sehingga fungsi tujuan metode goal programming adalah:

$$
\operatorname{Min} \sum_{i=1}^{m} D E_{i}+D A_{i}
$$

Secara umum model matematis goal programming dapat dirumuskan sebagai berikut,

$$
\operatorname{Min} \sum_{i=1}^{m} D B_{i}+D A_{i}
$$

$S T$

$$
\begin{aligned}
& a_{11} X_{1}+a_{12} X_{2}+\cdots+a_{1 n} X_{n}+D B_{1}-D A_{1}=b_{1} \\
& a_{21} X_{1}+a_{22} X_{2}+\cdots+a_{2 n} X_{n}+D B_{2}-D A_{2}=b_{2} \\
& a_{m 1} X_{1}+a_{m 2} X_{2}+\cdots+a_{m n} X_{n}+D B_{m}-D A_{m}=b_{m}
\end{aligned}
$$

Dan,

$$
X_{j,} D B_{i} \text { dan } D A_{i} \geq 0_{r} \text { untuk } t=1,2, \ldots, m
$$


Di dalam praktek organisasi, manajemen sering menghendaki suatu sasaran memperoleh prioritas untuk dicapai lebih dahulu disbanding prioritas-prioritas yang lain. Keinginan ini dapat dituangkan ke dalam model Goal Programming dengan cara mengatur urutan peminimuman variable deviasional.

Pemilihan variable deviasional yang harus diminimumkan pertama kali adalah persoalan arbitrasi dan bukan berdasarkan pedoman atau formulasi matematis tertentu. Inilah salah satu keunikan model Goal Programming. Di dalam penyelesaian goal programming, kita hanya perlu memberi suatu notasi kepada setiap variable deviasional di dalam fungsi tujuan agar dengan berpedoman notasi tersebut bias mengurutkan peminimuman variable deviasional sehingga sasaransasaran bisa dicapai sesuai dengan prioritas yang telah ditetapkan. Notasi yang digunakan untuk menandai prioritas sasaran tersebut adalah:

$P_{i}(I=1,2, \ldots, \mathrm{m})$ di mana $P_{i}$ bukan merupakan parameter atau variable melainkan hanya sebuah notasi untuk menandai urutan prioritas sasaran yang hendak dicapai.

Dengan demikian, bentuk umum fungsi tujuan model goal programming dengan prioritas sasaran adalah:

$$
\operatorname{Min} \sum_{i=1}^{M} P_{i}\left(D A_{i}+D B_{i}\right)
$$

\section{HASIL DAN PEMBAHASAN}

\section{Rata-rata Jumlah Permintaan Konsumen}

Rata-rata jumlah permintaan produk pupuk dapat dihitung dengan menjumlahkan data permintaan yang terjadi pada periode sebelumnya, yaitu dengan cara menjumlahkan permintaan tiap produk untuk tiap periodenya lalu dibagi dengan jumlah periode.

Jumlah permintaan pupuk organik dalam tri wulan terakhir:

$$
\begin{aligned}
& =211+181+193 \\
& =585 \text { ton }
\end{aligned}
$$

Rata-rata permintaan pupuk organik tiap bulannya adalah:

$$
=\frac{\mathrm{BgE}}{\mathrm{a}}=195 \text { ton }
$$

Jumlah permintaan pupuk anorganik dalam tri wulan terakhir:

$$
\begin{aligned}
& =117+98+124 \\
& =358 \text { ton }
\end{aligned}
$$

Rata-rata permintaan pupuk anorganik tiap bulannya adalah:

$$
=\frac{258}{3}=119,333 \approx 119 \text { ton }
$$

\section{Biaya Produksi dan Harga Jual Produk}

Total biaya produksi dan harga jual untuk tiap jenis pupuk yang dihasilkan per $\mathrm{Kg}$, dapat dilihat pada Tabel 1. 
Tabel 1 Biaya Produksi dan Harga Jual Pupuk

\begin{tabular}{cccc}
\hline No & Nama Produk & Harga Jual (Rp/Kg) & Biaya Bahan Baku (Rp/Kg) \\
\hline 1 & Pupuk organik & 1350 & 926 \\
2 & Pupuk anorganik & 6500 & 4550 \\
\hline
\end{tabular}

\section{Biaya Material Total}

Dilihat dari Tabel 1, maka dapat dihitung biaya material total yang diperlukan dan hasil penjualan dalam satu bulan serta keuntungan kotor perbulan adalah:

$$
\begin{array}{ll}
\text { Biaya material per bulan } & =(926 \times 195.000)+(4550 \times 119.000) \\
& =\text { Rp. } 722.020 .000,- \\
\text { Hasil penjualan per bulan } & =(1.350 \times 195.000)+(6.500 \times 119.000) \\
& =\text { Rp. } 1.036 .750 .000,- \\
\text { Keuntungan kotor per bulan } & =\text { Rp. } 1.036 .750 .000-\text { Rp. } 722.020 .000 \\
& =\text { Rp. } 314730000.670 .000,-
\end{array}
$$

\section{Waktu Proses Produksi}

Setelah menganalisa waktu kerja pada CV. G maka didapat perhitungan waktu proses produksi sebagai beriku. Pertama, jumlah rata-rata jam kerja karyawan per bulannya adalah 321 jam. Kedua, jumlah karyawan yang bekerja langsung untuk produksi 50 orang dengan rincian: produksi pupuk organik 30 orang dan produksi pupuk anorganik 20 orang. Ketiga, waktu proses tiap produk selama satu bulan adalah: pupuk organik $=320 \mathrm{jam} /$ bulan $\mathrm{x} 33$ orang $=10560 \mathrm{jam}$, serta pupuk anorganik $=320 \mathrm{jam} / \mathrm{bulan} \times 17$ orang $=5440 \mathrm{jam}$. Keempat, waktu proses produksi Tahap I (Persiapan) dan Tahap II (Pengolahan) selama satu bulan dapat dilihat pada Tabel 2.

Tabel 2 Waktu Proses Produksi Tahap I dan Tahap II

\begin{tabular}{cccc}
\hline Tahap & Pupuk Organik & Pupuk Anorganik & Waktu Pertahap (jam) \\
\hline I & 21 jam & 15 jam & $8235,789 \approx 8236$ \\
II & 17 jam & 19 jam & $7764,210 \approx 7764$ \\
Total & 38 jam & 34 jam & 16000 \\
\hline
\end{tabular}

\section{Pengolahan Data} adalah:

Peubah keputusan untuk model goal programming pada permasalahan yang terjadi di CV. G

$X_{1}=$ jumlah produksi pupuk organik

$X_{2}=$ jumlah produksi pupuk anorganik

Sasaran-sasaran (Goals) yang ingin dicapai oleh CV. G adalah: memaksimalkan jumlah produksi untuk memenuhi permintaan pelanggan, memaksimalkan pendapatan penjualan, meminimalkan biaya produksi, dan mengoptimalkan jam kerja karyawan.

Dari sasaran-sasaran yang telah ditetapkan, maka dapat dibentuk formulasi model goal programming sebagai berikut.

Pertama, sasaran memaksimalkan jumlah produksi untuk memenuhi permintaan pelanggan. Fungsi kendala 


$$
X_{i}+D B_{i}-D A_{i}=P_{i}
$$

Di mana:

$X_{i} \quad=$ jumlah produk $i$ yang diproduksi

$P_{i} \quad=$ tingkat permintaan produksi $i$

$D B_{i} \quad=$ nilai penyimpangan di bawah $P_{i}$

$D A_{i} \quad=$ nilai penyimpangan di atas $P_{i}$

Agar persamaan fungsi tujuan $\mathrm{Z}$ menjadi maksimum maka:

$$
\operatorname{Min} Z=\sum D B_{i}
$$

Kedua, sasaran memaksimalkan pendapatan penjualan.

Fungsi tujuan Z:

$$
\operatorname{Max} Z=\sum_{i=1}^{m} Q_{i} X_{i}
$$

Di mana:

$Q_{i} \quad=$ harga jual per unit produk $i$

$X_{i} \quad=$ jumlah produk $i$ yang di produksi

$m \quad=$ banyaknya jenis produk

Ketiga, sasaran meminimalkan biaya produksi.

Fungsi tujuan Z:

$$
\operatorname{Min} Z=\sum_{i=1}^{m} R_{i} X_{i}
$$

Di mana:

$R_{i} \quad=$ biaya produksi per unit per produk $i$

Keempat, sasaran mengoptimalkan jam kerja karyawan.

Fungsi kendala

$$
S_{i j} X_{i}+D B_{j}-D A_{j}=l K_{j}
$$

di mana:

$S_{i j} \quad=$ waktu proses per unit untuk jenis pemrosesan

$J K_{j} \quad=$ kapasitas jam kerja

$D B_{j} \quad$ = nilai penyimpangan di bawah $J K_{j}$

$\mathrm{DA}_{\mathrm{j}} \quad=$ nilai penyimpangan di atas $J K_{j}$

Fungsi tujuan Z:

$\operatorname{Min} Z=\sum D A_{Z} D B_{Z}$

Formulasi model di atas dapat diterapkan dalam tujuan yang ingin dicapai CV. Giri Senawa Mas Bali, dengan rumusan sebagai berikut.

Pertama, sasaran memaksimalkan jumlah produksi untuk memenuhi permintaan pelanggan. Jumlah permintaan produk berdasarkan total permintaan selama tri wulan terakhir dari bulan Oktober 2009 sampai dengan Desember 2009. Sasaran permintaan produk ini dapat diuraikan sebagai berikut:

$X_{1}+D B_{1}-D A_{1}=195$

$X_{2}+D B_{2}-D A_{2}=119$ 
Perusahaan menginginkan untuk memenuhi permintaan pelanggan, maka fungsi tujuannya adalah meminimalkan angka penyimpangan batas bawah $\left(\mathrm{DB}_{\mathrm{i}}\right)$ sebagaimana ditunjukkan oleh persamaan fungsi tujuan berikut:

$$
\begin{aligned}
& M \ln Z=\sum_{M \operatorname{Ln} Z}=D B_{i} \\
& M B_{1}+D B_{2}
\end{aligned}
$$

Kedua, sasaran memaksimalkan pendapatan penjualan. Perusahaan menginginkan pendapatan maksimal dari penjualan produk, sehingga fungsi tujuannya adalah:

$\operatorname{Max} Z=1350 X_{1}+6500 X_{2}$

Ketiga, sasaran meminimalkan biaya produksi. Perusahaan menginginkan total biaya produksi diminimalkan, sehingga fungsi tujuannya adalah:

$$
\operatorname{Min} Z=926 X_{1}+4550 X_{2}
$$

Keempat, sasaran mengoptimalkan jam kerja karyawan. Dari Tabel 2, sasaran mengoptimalkan jam kerja karyawan adalah

$$
\begin{aligned}
& 21 X_{1}+15 X_{2}+D B_{3}-D A_{3}=8235 \\
& 17 X_{1}+19 X_{2}+D B_{4}-D A_{4}=7764
\end{aligned}
$$

Perusahaan menginginkan untuk mengoptimalkan jam kerja karyawannya, sehingga fungsi tujuannya adalah:

$$
\operatorname{Min} Z=D B_{9}+D A_{9}+D B_{4}+D A_{4}
$$

Kendala-kendala yang telah disusun dan telah diformulasikan oleh Penulis akan diselesaikan program aplikasi yang telah dibuat, di mana penyelesaian menggunakan metode goal programming dan perhitungannya diselesaikan dengan metode simpleks yang telah dikembangkan.

\section{Implementasi}

Dari hasil pengolahan data maka dapat penulis rumuskan formulasi goal programming yang digunakan, sebagai berikut:

$$
\begin{aligned}
& M \operatorname{tn} Z=D B_{1}+D B_{2}+D B_{3}+D A_{3}+D B_{4}+D A_{4} \\
& M a x Z=1350 X_{1}+6500 X_{2} \\
& M \operatorname{tn} Z=926 X_{1}+4550 X_{2}
\end{aligned}
$$

Dengan kendala-kendala sebagai berikut:

$$
\begin{aligned}
& X_{1}+D B_{1}-D A_{1}=195 \\
& X_{2}+D B_{2}-D A_{2}=119 \\
& 21 X_{1}+15 X_{2}+D B_{8}-D A_{4}=8235 \\
& 17 X_{1}+19 X_{2}+D B_{4}-D A_{4}=7764
\end{aligned}
$$

Kendala tersebut diterapkan di dalam program aplikasi ini, dengan input jumlah kendala empat dan jumlah variabel dua, seperti terlihat pada Gambar 1 sebagai berikut. 


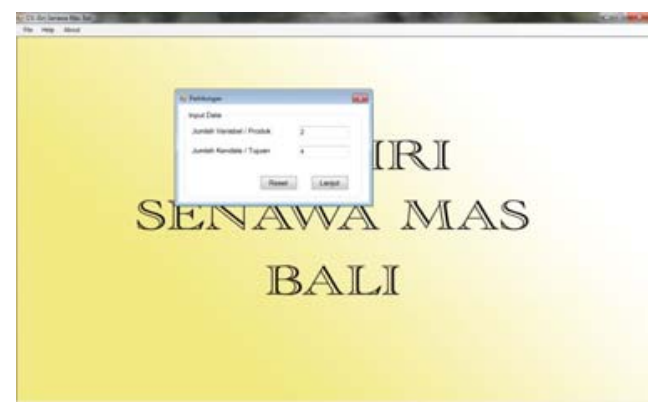

Gambar 1 Input Variabel dan Kendala

Setelah itu, isi data pada tabel sesuai dengan kendala yang ada, dan dengan bobot prioritas yang sama sesuai dengan fungsi tujuan yang ingin dicapai seperti Gambar 2.

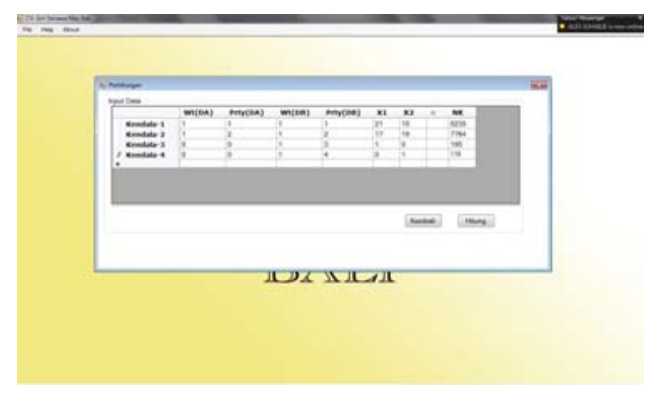

Gambar 2 Isi Tabel

Setelah tabel diisi dengan benar, maka hasil dari data yang telah diinput ditunjukkan pada tabel berikutnya, seperti pada Gambar 3 .

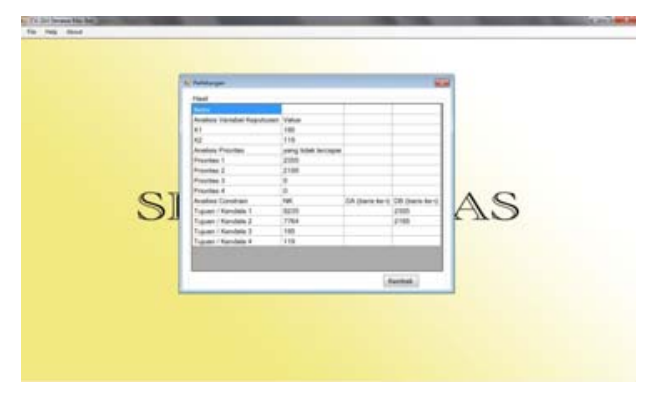

Gambar 3 Hasil Perhitungan

\section{Evaluasi}

Solusi optimal yang didapatkan setelah menghitung menggunakan program aplikasi ini untuk masing-masing variabel adalah:

$$
\begin{array}{ll}
X_{1} & =195 \text { ton } \\
X_{2} & =119 \text { ton } \\
D_{3} & =2355 \mathrm{jam} \\
\mathrm{DB}_{4} & =2188 \mathrm{jam}
\end{array}
$$

di mana $\mathrm{X}_{1}$ adalah mewakili produk pupuk organik dan $\mathrm{X}_{2}$ mewakili produk pupuk anorganik. Pencapaian masing-masing tujuan dapat dilihat pada Tabel 3. 
Tabel 3 Hasil Evaluasi

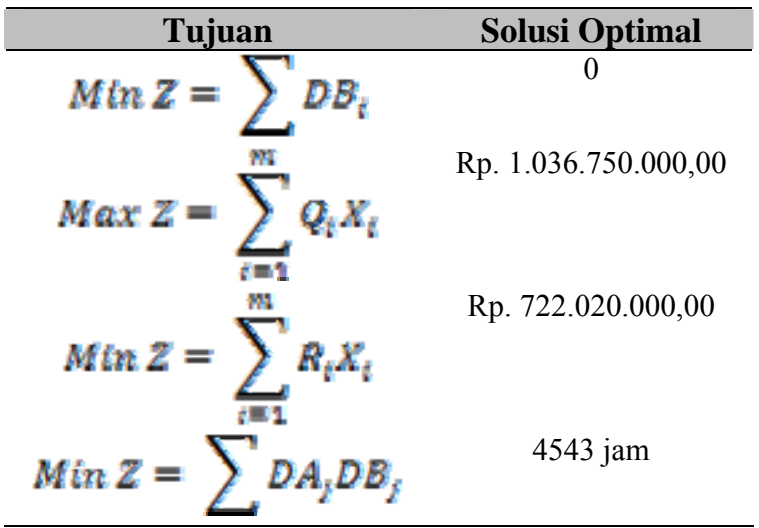

Dari hasil analisis pada Tabel 3, maka dapat dijelaskan bahwa jumlah produk X1 (pupuk organik) dan $\mathrm{X}_{2}$ yang akan diproduksi tercapai, yaitu sebanyak 195 ton dan 119 ton. Dari Tabel tersebut, dapat dijelaskan juga bahwa dengan kombinasi produk optimal X1 dan X2, maka: pertama, sasaran memenuhi kebutuhan permintaan konsumen terpenuhi dengan total penyimpangan DBi (DB1 dan DB2) adalah nol; kedua, sasaran memaksimumkan pendapatan hasil produksi adalah sebesar Rp. 1.036.750.000,00; ketiga, sasaran meminimumkan biaya produksi yaitu Rp. 722.020.000,00; serta sasaran mengoptimalkan jam kerja karwayan mengalami penyimpangan batas bawah $\left(\mathrm{DB}_{3}\right.$ dan $\left.\mathrm{DB}_{4}\right)$ sebesar 4543 jam. Ini berarti jam kerja karyawan di perusahaan ini masih belum dimanfaatkan sebanyak 4543 jam.

\section{SIMPULAN}

Berdasarkan penelitian yang telah dilakukan di CV. G dengan melakukan analisis system dan perancangan program aplikasi, maka kesimpulan yang dapat diambil adalah: sasaran mengoptimalkan jumlah produk yang diproduksi agar dapat memenuhi permintaan konsumen dapat tercapai dengan produksi produk pupuk organik sejumlah 195 ton dan pupuk anorganik sejumlah 119 ton; sasaran pendapatan memaksimalkan pendapatan dan meminimalkan biaya produksi tercapai; keuntungan optimal yang dapat diperoleh adalah Rp. 314.730.000,00; serta dilihat dari hasil olah data menggunakan goal programming jam kerja karyawan pada CV. G belumlah dapat dimanfaatkan sepenuhnya, atau dengan kata lain jam kerja pada perusahaan ini berlebihan.

\section{DAFTAR PUSTAKA}

Bronson, R., and Naadimuthu, G. (1997). Schaum's outline of theory and problems of operation research, New York: McGraw Hill.

Ching, W. K., and Zhou, X. Y. (1996). Matrix methods in production planning of failure prone manufacturing systems. Lecture notes in control and information sciences 21-recent advances in control and optimization of manufacturing systems, Springer-Verlag, 3-29.

Dauzere-Peres, S., Gershwin, S. B., and Sevaux, M. (2000). Models and solving procedures for continuous-time production planning, IIE Transactions, 32(2), 93-103. 
Huang, L., Hu, J. Q., and Vakili, P. (1996). Optimal control of a failure prone manufacturing system with the possibility of temporary increase in production capacity. Lecture notes in control and information sciences 21-recent advances in control and optimization of manufacturing systems, Springer-Verlag, 31-60.

Mulyono, S. (2004). Riset operasi, Jakarta: Fakultas Ekonomi, Universitas Indonesia.

Perkins, J. R., and Srikant, R. (1996). Optimal control of manufacturing systems with buffer holding costs. Lecture notes in control and information sciences 21-recent advances in control and optimization of manufacturing systems. Springer-Verlag, 61-96.

Siswanto. (2007). Operations research, jilid pertama, Jakarta: Erlangga.

Taha, H. A. (2007). Operation research: an introduction, Prentice Hall. 